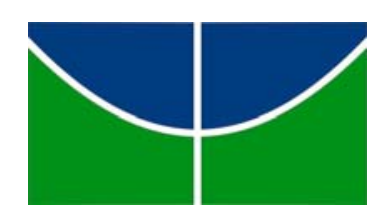

Universidade de Brasília

Centro de Excelência em Turismo

Curso de Especialização em Ecoturismo

\title{
SÃO JOÃO: A ALIANÇA ENTRE O NATURAL E O CULTURAL
}

\author{
Michelle Franco Coelho
}

Orientadora: Prof. Dra. Tânia Montoro

Brasília, setembro de 2004. 


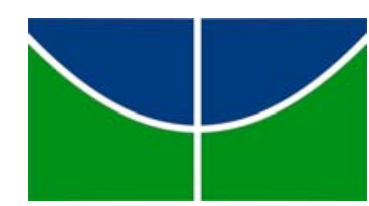

Universidade de Brasília

Centro de Excelência em Turismo

Curso de Especialização em Ecoturismo

\section{SÃO JOÃO: A ALIANÇA ENTRE O NATURAL E O CULTURAL}

Monografia apresentada ao Centro de Excelência em Turismo da Universidade de Brasília como exigência parcial para obtenção do certificado de Especialista em Ecoturismo.

Aluna: Michelle Franco Coelho

Orientadora: Prof. Dra. Tânia Montoro

Brasília, setembro de 2004. 
Coelho, Michelle Franco

São João: a Aliança entre o Natural e o Cultural / Michelle Franco Coelho f.

Monografia (Especialização em Ecoturismo) - Universidade de Brasília. Centro de Excelência em Turismo. Brasília, 2004.

Orientadora: Prof. Dra. Tânia Montoro

1. Ecoturismo 2. Sustentabilidade 3. Cultura 4. Patrimônio Cultural

5. Espaço Cultural 
Aos meus avós e avôs, pela proteção e sabedoria de vida; aos meus pais, pelo eterno amor $\mathrm{e}$ compreensão; a minha irmã e seu namorado, pela paciência; ao meu namorado, pelo carinho e companheirismo; e a todos os meus amigos. 
Agradeço à professora Tânia Montoro e às pessoas que colaboraram para a realização do trabalho: Renilze, Zéria, Nádia, Clauderson, Carlinhos e Leila Chalub. 
Deixe-me ir, preciso andar Vou por aí a procurar Rir pra não chorar Quero assistir ao sol nascer Ver as águas dos rios correr Ouvir os pássaros cantar Eu quero nascer, quero viver Se alguém por mim perguntar Diga que eu só vou voltar Quando eu me encontrar (Cartola) 
RESUMO

O estudo pretende valorizar o patrimônio natural e cultural de São João D’Aliança, município localizado na Chapada dos Veadeiros, estado de Goiás.

Os conceitos de turismo, desenvolvimento sustentável, ecoturismo, cultura, patrimônio e folclore são apresentados no primeiro capítulo do trabalho.

A metodologia utilizada baseou-se na pesquisa bibliográfica e documental, em entrevistas e registros fotográficos. Foram realizadas duas visitas ao município.

Tem-se, no terceiro capítulo, a descrição do Pólo Ecoturístico Chapada dos Veadeiros, da história de São João, da demanda turística, dos atores sociais do turismo, da infra-estrutura e dos atrativos naturais e culturais de São João. A dança Catira e os produtos locais são elementos culturais que enriquecem a experiência do turista e proporcionam benefícios à própria população local e à atividade ecoturística.

Ao final do trabalho, a proposta de criação de um espaço cultural concretiza a preservação e divulgação da cultura local, além de contribuir ao desenvolvimento sustentável do Ecoturismo. 


\section{ABSTRACT}

The study intends to appreciate the natural and cultural patrimony of São João D'Aliança, city located at Chapada dos Veadeiros, state of Goiás, Brazil.

The concepts of tourism, sustainable development, ecotourism, culture, patrimony and folklore are presented on chapter one.

The methodology used was based on documental and bibliographical research, interviews and photographic registers. Two visits to the city had been carried out.

The third chapter presents a description of Pólo Ecoturístico Chapada dos Veadeiros and the history of São João. It also brings a diagnostic of the tourist demand, identifies the social actors who promote the tourism activity and lists the natural and cultural attractions of São João D'Aliança. The Catira dance and the local products are cultural elements that enrich the tourist's experience and bring benefits to the own local population and to the ecotourism activity.

At the end of the work, the proposal of creation of a cultural center materializes the preservation and release of the local culture, and also contributes to the sustainable development of the Ecotourism. 


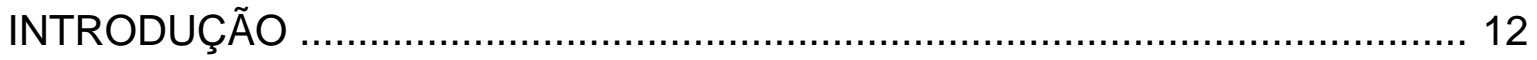

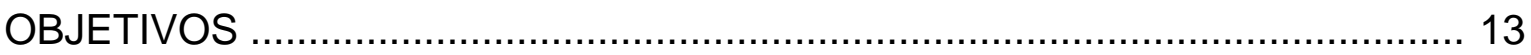

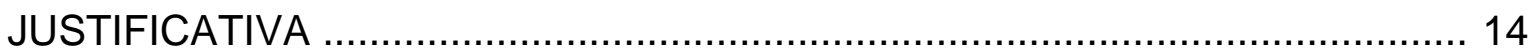

1. FUNDAMENTAÇÃO TEÓRICA ……….............................................. 15

1.1 Turismo e Sustentabilidade ………..................................................... 15

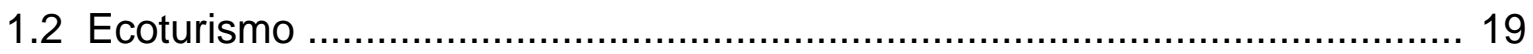

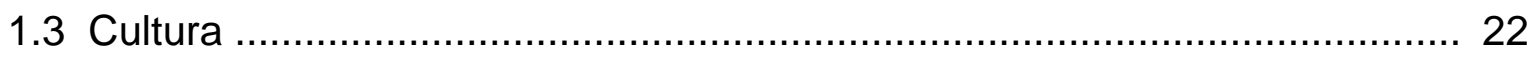

1.3.1 Patrimônio Cultural .......................................................................... 23

1.3.2 Patrimônio Imaterial ......................................................................... 25

1.3.3 Cultura Popular e Folclore ................................................................. 26

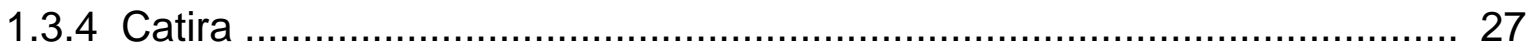

2. PROCEDIMENTOS METODOLÓGICOS ……........................................ 30

3. CARACTERIZAÇÃO DO AMBIENTE DE PESQUISA ................................. 31

3.1 Pólo Ecoturístico Chapada dos Veadeiros …………................................. 31

3.2 O Município de São João D’Aliança ………………...................................... 34

3.2.1 Atrativos Naturais e Culturais ……………......................................... 36

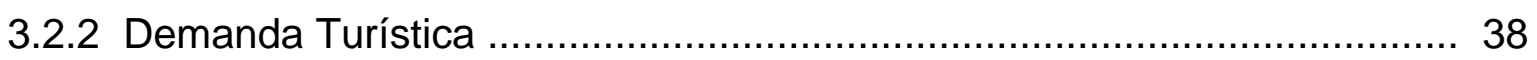

3.2.3 Infra-estrutura e Serviços ................................................................... 39

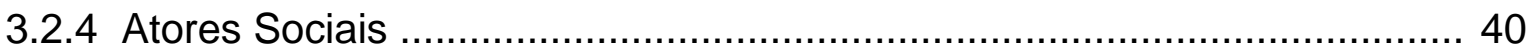

3.3 Patrimônio Cultural de São João D’Aliança ……………………………..... 41

3.3.1 A Catira de São João D’Aliança ............................................................. 41 
3.3.2 O Artesanato e os Produtos Típicos de São João D'Aliança

4. CRÍTICAS E SUGESTÕES

5. PROPOSTA PARA A CRIAÇÃO DE UM ESPAÇO CULTURAL

CONCLUSÃO 55

BIBLIOGRAFIA 56 


\section{INTRODUÇÃO}

O turismo é a atividade econômica que mais gera divisas em todo o mundo, atingindo mais de 52 setores da economia. Considerado um fenômeno social, o turismo se expandiu rapidamente, tornando-se uma atividade altamente complexa, capaz de movimentar e empregar milhões de pessoas e centenas de bilhões de dólares a cada ano.

Como segmento turístico de maior crescimento, o ecoturismo busca a conscientização ambiental e a preservação do patrimônio natural e cultural, além de almejar benefícios às comunidades envolvidas.

O enfoque do presente trabalho é evidenciado a partir da importância do ecoturismo desenvolvido na Chapada dos Veadeiros junto à preocupação com o patrimônio cultural de São João D'Aliança, município que integra a Chapada.

Pretende-se mostrar a peculiaridade e a riqueza das manifestações culturais de São João por meio do estudo em campo. Quer-se esclarecer também, a necessidade de ações que valorizem a cultura local e tragam melhor qualidade de vida à população, além de enriquecerem a experiência do turista.

Partindo-se desta necessidade, a proposta de concepção de um espaço cultural se torna interessante. Como poderoso instrumento de divulgação cultural, o espaço pretende contribuir ao desenvolvimento do ecoturismo e da região de pesquisa. 
OBJETIVOS

Objetivo geral

Agregar valor cultural ao ecoturismo da Chapada dos Veadeiros, valorizando a cultura de São João D'Aliança por meio da criação de um espaço cultural.

Objetivos específicos

Identificar o patrimônio natural e cultural do município de São João D'Aliança;

Descrever a demanda turística, a infra-estrutura, os serviços e os atores sociais do município;

Identificar problemas locais e sugerir soluções ao desenvolvimento local e turístico;

Analisar as manifestações e produções culturais como atrativo turístico;

Promover e preservar os aspectos culturais locais através da implementação de um espaço cultural em São João D’Aliança;

Divulgar a Catira de São João e estimular a produção dos produtos locais; Mostrar a possibilidade de interação entre a comunidade local e os turistas. 


\section{JUSTIFICATIVA}

Diversos foram os motivos que justificaram as investigações e a escolha do tema. A começar pela proximidade do município de São João D’Aliança e sua localização na Chapada dos Veadeiros, área de grande atratividade para o ecoturismo.

Não foram encontrados estudos acadêmicos sobre o município; há monografias e teses sobre os municípios vizinhos de Alto Paraíso e Vila de São Jorge e Cavalcante. Portanto uma forte razão foi a carência de informações e estudos sobre São João D’Aliança.

Sabe-se que o município apresenta índices de baixa qualidade de vida. Diante deste problema, espera-se que a proposta do estudo ultrapasse os limites acadêmicos e contribua para o desenvolvimento social de São João.

Outro motivo que se considera importante é a falta de espaço físico para a divulgação das manifestações culturais e a limitação de espaço para a venda de produtos e artesanatos locais. 


\section{FUNDAMENTAÇÃO TEÓRICA}

\subsection{TURISMO E SUSTENTABILIDADE}

Embora o turismo tenha suas origens tão antigas quanto a própria história da humanidade, seu estudo de forma científica se iniciou há poucas décadas. Mesmo apresentando natureza pluridisciplinar por englobar conhecimentos de diversas áreas e ciências, o turismo não constitui uma ciência. Este fato, porém, não impossibilita seu merecido destaque acadêmico e aprofundamento técnico-científico.

O turismo se enquadra em um universo maior denominado lazer. Entendese por lazer todas as atividades desenvolvidas fora do sistema produtivo, das obrigações sociais, religiosas e familiares. As viagens, assim como o turismo são um direito legítimo de todo cidadão e constituem uma das atividades do lazer que podem ser realizados por diversos motivos como prazer e diversão, congressos, feiras e convenções, negócios ou reuniões técnicas profissionais, eventos esportivos, políticos ou sociais, religião, contato com a natureza, saúde e finalidades artísticas ou culturais.

Atualmente tem-se uma grande diversidade de conceitos e definições sobre turismo que foram evoluindo conforme o desenvolvimento e a abrangência das áreas que o turismo se relaciona.

"O turismo, numa abordagem simplificada, é um tipo específico de deslocamento, praticado por um tipo singular de viajante, o turista, que se diferencia dos demais por objetivos de viagem, tempo de permanência e estado de espírito".(MONTORO, 2003, p.15). 
A Organização Mundial do Turismo (OMT) define turismo como "o deslocamento para fora do local de residência por período superior a 24 horas e inferior a 60 dias motivado por razões não-econômicas".

Oscar de La Torre (apud IGNARRA, 1999) conceituou da seguinte forma:

o turismo é um fenômeno social que consiste no deslocamento voluntário e temporário de indivíduos ou grupos de pessoas que, fundamentalmente por motivos de recreação, descanso, cultura ou saúde, saem de seu local de residência habitual para outro, no qual não exercem nenhuma atividade lucrativa nem remunerada, gerando múltiplas inter-relações de importância social, econômica e cultural.

Além da importância de base conceitual, o turismo se transformou em um fenômeno de enorme relevância para a esfera social e econômica. É o setor econômico que apresenta os índices mais elevados de crescimento no contexto mundial. As estimativas sociais demonstram uma crescente geração de trabalho e de renda com a surpreendente expansão das atividades turísticas. A OMT (1994) prevê para o ano de 2005 uma expansão global do turismo, com a geração de 72 trilhões de dólares em receita bruta, criação de empregos para 305 milhões de pessoas, produção equivalente a $11,4 \%$ do produto global bruto e investimento de mais de 1.600 bilhões de dólares em facilidades e equipamentos. Para o turismo nacional, a previsão é de um crescimento de pelo menos 9 a 10\% ao ano.

Assunto polêmico que abrange todas as esferas do turismo e constitui um desafio para a vida em sociedade, a sustentabilidade busca a mudança do paradigma de desenvolvimento econômico atual e a construção de uma sociedade que favoreça a qualidade de vida desta e das futuras gerações. 
A preocupação do homem com a questão da sustentabilidade, principalmente em sua perspectiva ambiental e educacional, tem se concretizado há algumas décadas. Vale ressaltar as publicações "Primavera Silenciosa", de Carlson (1962) e o relatório "Os Limites do Crescimento" (The Limits of Growth), publicado pelo Clube de Roma - grupo de cientistas e autoridades envolvidos com questões ambientais - como um sinal de alerta para o crescimento populacional e o consumo insustentável dos recursos naturais. Este relatório constituiu ponto de partida para a Conferência das Nações Unidas sobre o Meio Ambiente, realizada em Estocolmo no ano de 1972, tendo como destaque os direitos da humanidade a um ambiente saudável e produtivo. Em seguida, aconteceu em Belgrado o Encontro Internacional da United Nations Educational, Scientific and Cultural Organization (UNESCO) em 1975. Como resultado deste encontro surge a "Carta de Belgrado" e a necessidade de um novo conceito de desenvolvimento. Em 1977, a Conferência de Tblisi, na Geórgia, como ressalta Irving (2002), estabelece as premissas básicas para o desenvolvimento da educação ambiental e enfatiza a necessidade de integração das diferentes formas de conhecimento, a consideração da identidade cultural, a busca de soluções para o equacionamento da problemática ambiental, entre outros. 0 compromisso sobre a conscientização em relação às causas e conseqüências da problemática do meio ambiente foi estabelecido na 22a $\underline{\text { a }}$ Conferência Geral da UNESCO para o Programa Internacional de Educação Ambiental, em 1983. A publicação do documento "Nosso Futuro Comum" em 1987, pela Comissão Mundial sobre o Meio Ambiente e Desenvolvimento, oficializou e legitimou internacionalmente a proposta de desenvolvimento sustentável como novo paradigma de desenvolvimento para as sociedades humanas (grifo nosso). 
A sustentabilidade do turismo foi abordada de forma mais consistente a partir da histórica Conferência das Nações Unidas sobre o Meio Ambiente e Desenvolvimento, mais conhecida como Rio 92. Documento assinado no Rio de Janeiro pelos representantes de 200 países, a Agenda 21 representa uma releitura contextualizada da "Carta de Belgrado" e da Conferência de Tblisi, com o objetivo de preparação do mundo para os desafios do século que estamos vivenciando no momento. De enorme contribuição ao turismo, abordagens como a ética no turismo, o turismo e o desenvolvimento sustentável, a valorização de comunidades nativas, os meios de comunicação e a disseminação de conhecimentos tradicionais estão incluídas nos conteúdos dos tópicos da Agenda 21.

A missão de internalizar o conceito de sustentabilidade e de desenvolvimento sustentável na sociedade brasileira foi reforçada por meio da elaboração e implementação da Agenda 21 brasileira, processo iniciado em 1999. Turismo e desenvolvimento sustentável são novamente discutidos em Joanesburgo, na África do Sul, com a II Conferência Mundial para o Desenvolvimento Sustentável, a Rio + 10, estabelecendo um reordenamento da Agenda 21 por meio da análise dos resultados após a Rio 92 e de um novo direcionamento de estratégias governamentais que condicionarão a implementação do desenvolvimento sustentável em diversos setores como o turismo, educação, cultura, comunicação, geração de emprego e renda, além de muitos outros.

Apesar dos desafios e limitações a respeito de sua aplicabilidade e efetividade, constatou-se, a partir dos acontecimentos e marcos descritos, que a sustentabilidade começa a integrar o planejamento do turismo, mobilizando o poder público, a iniciativa privada, a sociedade civil organizada e os turistas para a conscientização e integração do desenvolvimento turístico. 


\subsection{ECOTURISMO}

O crescimento do turismo proporcionou, ao longo dos anos, sua diversificação em segmentos de consumo baseados em diferentes interesses e necessidades dos turistas. Como segmento de maior expansão, o ecoturismo é discutido e almejado em praticamente todo o mundo.

Para a compreensão do surgimento do ecoturismo cabe relembrar a influência do ambientalismo contemporâneo junto ao interesse científico. A história do ambientalismo se inicia a partir da década de 1940, quando começam a surgir pesquisas científicas voltadas para os recursos naturais do planeta. As publicações, conferências, encontros, discussões e definições na área de turismo e sustentabilidade, descritas no capítulo anterior, se complementam aos movimentos ambientalistas e os de caráter político-ideológico e contracultural e impulsionam a formação da atividade ecoturística.

No contexto brasileiro, a definição de ecoturismo contida na publicação “Diretrizes para uma Política Nacional de Ecoturismo" é a seguinte:

um segmento da atividade turística que utiliza, de forma sustentável, o patrimônio natural e cultural, incentiva sua conservação e busca a formação de uma consciência ambientalista através da interpretação do ambiente, promovendo o bem-estar das populações envolvidas. (Instituto Brasileiro de Turismo - Embratur, 1994).

O manual de ecoturismo, elaborado pela World Wild Foundation (WWF) do Brasil diz que as primeiras definições de ecoturismo associavam a atividade apenas à função de preservação do ambiente natural. Estas definições passaram a ser 
reelaboradas a partir da evolução do conceito de desenvolvimento sustentável e da inclusão do homem no processo de sustentabilidade. A definição do Embratur, portanto, acompanhou uma nova tendência do ecoturismo mundial, incorporando a população envolvida nos benefícios da atividade turística.

Salvati (2002) demonstra que três grandes eixos temáticos sustentam o conceito brasileiro de ecoturismo: a sustentabilidade, a educação do visitante e os benefícios às comunidades locais.

A sustentabilidade depende da conservação dos ambientes natural e cultural. A utilização racional dos recursos naturais é imprescindível à manutenção do ecoturismo a médio e longo prazo, principalmente para as unidades de conservação (UCs) como parques, reservas, áreas de proteção ambiental e florestas. O reconhecimento e respeito ao patrimônio histórico-cultural dos povos devem ser considerados em prol da preservação e divulgação de bens culturais.

Para a questão educacional do ecoturismo, a educação do visitante é fundamental à valorização das culturas locais, além da atividade ecoturística proporcionar ao visitante a conscientização da importância de se preservar a natureza, a história e a cultura dos locais de visitação. A interpretação do ambiente natural desperta o turista a transformar seus hábitos cotidianos e a lutar por um ambiente mais harmônico para viver.

Como meta maior do ecoturismo, o desenvolvimento socioeconômico sustentável de um lugar é atingido quando existe um envolvimento das comunidades com a preocupação de gerar benefícios locais. Para isso, a comunidade deve estar engajada desde a fase inicial do planejamento turístico, mostrando suas necessidades prioritárias e suas expectativas. 
Dentro do contexto de benefícios que o ecoturismo pode trazer às comunidades, os desafios e princípios descritos a seguir, servirão como elementos que justificarão a proposta final do trabalho.

O ecoturismo tem poder para promover a valorização cultural das comunidades por meio da preservação e divulgação da cultura local, do conhecimento de processos históricos de colonização e uso da terra, da articulação e promoção de políticas públicas e estratégias de marketing a favorecer as comunidades.

A diversificação e integração econômica devem ser almejadas pelo ecoturismo em busca da melhoria da qualidade de vida das comunidades. Portanto o ecoturismo pode ser a atividade complementar e integrada às outras atividades locais, permitindo assim um contínuo suporte de incentivos à produção de artesanatos, alimentos e bebidas e até mesmo de serviços diversos. Outro ponto que contribui para o desenvolvimento socioeconômico é a organização de organismos ou entidades locais que se mobilizem e estabeleçam mecanismos capazes de garantir a alta qualidade dos produtos ecoturísticos e culturais tanto à comunidade quanto aos turistas e o retorno econômico ao município e região. Um exemplo concreto é o arrecadamento de taxas e impostos e a criação de um fundo de turismo. 


\subsection{CULTURA}

Foi esclarecido que um dos princípios do ecoturismo é a valorização da cultura local. Mediante esta afirmação é essencial que os termos cultura, patrimônio e folclore sejam analisados.

De origem latina, a palavra cultura está relacionada, em seu significado original, às atividades agrícolas. Vem do verbo latino colere, que quer dizer cultivar.

A cultura faz parte de uma realidade onde a mudança é um aspecto fundamental. Portanto, é uma dimensão dinâmica da sociedade que inclui todo o conhecimento num sentido ampliado e todas as maneiras como esse conhecimento é expresso.

A primeira concepção de cultura remete a todos os aspectos de uma realidade social; a segunda refere-se mais especificamente ao conhecimento, às idéias e crenças de um povo. (SANTOS, 1996, p.23).

Selecionou-se, de diversas definições de "cultura", a partir dos dicionários Aurélio e Michaelis, como as mais pertinentes para este trabalho, as abaixo:

O conjunto complexo dos códigos e padrões que regulam a ação humana individual e coletiva, tal como se desenvolvem em uma sociedade ou grupo específico, e que se manifestam em praticamente todos os aspectos da vida: modos de sobrevivência, normas de comportamento, crenças, instituições, valores espirituais, criações materiais, etc. [Como conceito das ciências humanas, esp. da antropologia, cultura pode ser tomada abstratamente, como manifestação de um atributo geral da humanidade, ou, mais concretamente, como patrimônio próprio e distintivo de um grupo ou sociedade específica.]. 
A parte ou o aspecto da vida coletiva, relacionados à produção e transmissão de conhecimentos, à criação intelectual e artística, etc.; o processo ou estado de desenvolvimento social de um grupo, um povo, uma nação, que resulta do aprimoramento de seus valores, instituições, criações, etc.;civilização, progresso; estado ou estágio do desenvolvimento cultural de um povo ou período, caracterizado pelo conjunto das obras, instalações e objetos criados pelo homem desse povo ou período; conteúdo social.

Portanto, o que se enfoca a seguir é vinculado a essa ótica cultural, ou seja, o material e o imaterial criados e preservados pelo povo brasileiro, através dos tempos, e que constituem o nosso patrimônio cultural.

\subsubsection{PATRIMÔNIO CULTURAL}

A origem etimológica de patrimônio vem do latim patrimonium, que se associa à idéia de bens herdados do pai (pater) ou bens de família.

Apesar da palavra "patrimônio" possuir sentidos diversos, somente no século XVIII, quando, na França, o poder público começou a tomar as primeiras medidas de proteção aos monumentos de valor para a história das nações, o uso de "patrimônio" estendeu-se para os bens protegidos por lei e pela ação de órgãos especialmente constituídos, nomeando o conjunto de bens culturais de uma nação. 
Segundo Ferri e Ruschmann (2000, p.23), patrimônio cultural "é o conjunto de bens materiais, culturais, simbólicos e espirituais de uma sociedade, nos quais se incluem os conjuntos urbanos, arquitetônicos e os sítios de valor histórico, paisagístico, arqueológico, paleontológico e científico".

A evolução de conceitos estabelecidos pela Constituição Federativa do Brasil demonstra que os bens de natureza imaterial, que serão definidos adiante, foram inclusos nas políticas públicas de cultura somente a partir de 1988. Percebese também que o termo "patrimônio histórico e artístico" teve seu conteúdo ampliado para "patrimônio cultural".

Pelo Decreto-lei no 25, de 30 de novembro de 1937, patrimônio histórico e artístico é definido como "o conjunto de bens móveis e imóveis existentes no país e cuja conservação seja de interesse público, quer por sua vinculação a fatos memoráveis da história do Brasil, quer por seu excepcional valor arqueológico ou etnológico, bibliográfico ou artístico".

Já a definição estabelecida pela Constituição da República Federativa do Brasil de 1988, conforme o artigo 216, é a seguinte:

Constituem o patrimônio cultural brasileiro, os bens de natureza material e imaterial, tomados individualmente ou em conjunto, portadores de referência à identidade, à ação, à memória dos diferentes grupos formadores da sociedade brasileira, nos quais se incluem:

I - as formas de expressão;

II - os modos de criar, fazer e viver;

III - as criações científicas, artísticas e tecnológicas;

IV - as obras, objetos, documentos, edificações e demais espaços destinados às manifestações artístico-culturais; 
V - os conjuntos urbanos e sítios de valor histórico, paisagístico, artístico, arqueológico, paleontológico, ecológico e científico.

\subsubsection{PATRIMÔNIO IMATERIAL}

A sociedade confere valor especial não somente e exclusivamente aos bens materiais. As diferentes formas de expressão, os peculiares modos de criar e viver são exemplos riquíssimos de bens culturais de natureza imaterial.

Com simplicidade e brilhantismo, Cecília Londres (2004, p. 21) exalta que:

patrimônio é tudo que criamos, valorizamos e queremos preservar: são os monumentos e obras de arte, e também as festas, músicas e danças, os folguedos e as comidas, os saberes, fazeres e falares. Tudo enfim que produzimos com as mãos, as idéias e a fantasia.

O interesse pelos produtos da cultura popular, que hoje são objetos da legislação brasileira, já era preocupação do escritor Mário de Andrade desde a segunda década do século $X X$.

Patrimônio imaterial engloba todas as formas tradicionais e populares de cultura transmitidas oralmente ou por gestos e que, com o passar do tempo, são modificadas por meio de processo de recriação coletiva. Isto inclui tradições orais, costumes, idiomas, música, dança, rituais, festividades, artes culinárias, medicina tradicional e outras. 
O Brasil foi o precursor de uma política específica para o assunto, ao instituir o Registro de Bens Culturais de Natureza Imaterial e criar o Programa Nacional do Patrimônio Imaterial. A legislação foi efetivada por meio do Decreto 3551, de 04 de agosto de 2000, concretizando a antiga preocupação dos modernistas da década de 1920, principalmente Mário de Andrade, com o reconhecimento e a preservação do nosso patrimônio imaterial.

\subsubsection{CULTURA POPULAR E FOLCLORE}

Esses dois termos têm significados muito equivalentes para alguns especialistas no assunto, mas é objeto de diferenciações para outros.

Para um melhor entendimento, faz-se necessário estabelecer que a compreensão didática de cultura envolve a sua partição em três aspectos: cultura erudita, cultura espontânea e cultura popular.

Araújo (1997, p. 09) conceitua que "a cultura procedente do ensinamento direto, ministrada nas organizações intelectuais - escolas, academias, universidades, igrejas, imprensa, cinema - denomina-se cultura erudita". Ainda defende que "a cultura aprendida indiretamente na vivência da sociedade, na troca de experiência do homem com seu semelhante, desde o nascimento até a morte, chama-se cultura espontânea". Esta última é entendida como não dirigida e não orientada. 
De modo simplificado, pode-se dizer que a cultura popular é a interação da cultura erudita com a cultura espontânea.

O folclore, termo aportuguesado, originado de folklore, da língua inglesa folk (povo) + lore (saber; estudo; ciência) - entende-se como sendo: "o saber do povo"; a expressão de seus costumes tradicionais, crenças, superstições, cantos, festas, indumentárias, lendas, artes etc., conservados no seio de um povo.

A interpretação mais usual sobre folclore o situa como inserido na cultura popular, de forma bastante abrangente, e mais especificamente na cultura espontânea.

O folclore brasileiro é complexo e extenso. Todavia, dele pretende-se abordar mais especificamente os segmentos da dança popular, em particular a dança conhecida como Catira (presente na maioria das festas populares); o artesanato; e os produtos típicos. Todos de ocorrência na cidade de São João D'Aliança - GO.

\subsubsection{CATIRA}

A Catira é uma dança rural, também conhecida por Cateretê e por Xiba. De origem incerta e muito discutida, seu nome vem do Tupi e, embora seja tida como ameríndia brasileira, sua coreografia assemelha-se aos processos africanos de dançar. Diz-se poder ser também de origem espanhola ou portuguesa. De concreto 
mesmo só a sua rica e folclórica existência, pouco registrada até o século XIX, mas fartamente documentada nos dias atuais.

Foi incorporada pelo padre Anchieta às suas festas católicas de catequese no século XVI e hoje é praticada mais intensamente nos estados de São Paulo, Rio de Janeiro, Minas Gerais, Mato Grosso e Goiás. Comenta-se sobre sua ocorrência nas regiões Nordeste e Norte (Amazônia e Pará).

Pertence ao núcleo de danças palmeados e sapateados. A dança tem alguns elementos fixos, apresentando variações na música e na coreografia. É dançada em fileiras opostas de dez participantes, acompanhados por uma dupla de violeiros, que alternam "as modas" com a atuação dos catireiros.

Os violeiros cantam e batem os pés, não batem palmas. Os dançantes não cantam, mas batem palmas e pés. No centro do salão os dançadores formam duas colunas, tendo à testa delas um violeiro cantador. Um dos violeiros é o mestre e o outro é contra-mestre. "Mestre" é a designação popular dada ao violeiro que faz a primeira voz e também é o autor da "moda" que vai ser cantada. "Contra-mestre" é o que faz a segunda voz. Entre dançantes e violeiros na coluna em que está o mestre fica o "tirador de palmas" e na outra o "tirador de sapateado". Não raro, um exerce as duas funções de determinar o momento das batidas de palmas e do bater dos pés, execução do pateio, porque batem com o pé em cheio no solo.

A Catira se inicia com o canto intitulado de "cabeçalho" (saudação que se faz aos violeiros), entoando a mesma melodia da moda ao som do palmeado e do sapateado, e é finalizada sempre com o "recortado", uma letra marcada pelo caráter de humor.

A Catira é hoje apresentada nas Folias de Reis, nas Festas do Divino e em outras festanças populares. Não é dança de terreiro, mas de salão. 
Os temas das "modas" estão ligados ao cotidiano - trabalho, amores, estórias, etc.

Num dos trechos da bela Vide-Vida Marvada, canta Rolando Boldrin:

$$
\begin{gathered}
\text { “... É que a viola fala alto } \\
\text { no meu peito humano } \\
\text { e toda moda é um remédio } \\
\text { pros meus desenganos } \\
\text { é que a viola fala alto } \\
\text { no meu peito, mano } \\
\text { e toda mágoa é um mistério } \\
\text { fora deste plano } \\
\text { prá todo aquele que só fala } \\
\text { que eu não sei viver } \\
\text { chega lá em casa } \\
\text { pruma visitinha } \\
\text { que no verso e no reverso } \\
\text { da vida inteirinha } \\
\text { há de me encontrar } \\
\text { num cateretê...” }
\end{gathered}
$$

O traje é comum. Em geral todas as danças são realizadas à noite.

Outrora essencialmente masculina, muitos grupos já admitem a participação de mulheres, que devem, tanto quanto os homens, demonstrar habilidades rítmicas com os pés e com as mãos.

A dança serve também como identidade familiar para os integrantes do grupo. 


\section{PROCEDIMENTOS METODOLÓGICOS}

A pesquisa foi realizada por meio da abordagem qualitativa. Para isso, utilizou-se a pesquisa bibliográfica e documental com base em livros, jornais, sites oficiais, relatórios e mapas.

Para o enriquecimento do trabalho, a pesquisa em campo foi desenvolvida durante duas visitas ao município de São João D'Aliança, onde foi possível observar e fazer um levantamento geral das condições turísticas do local. Realizouse entrevistas semi-estruturadas com representantes de organizações nãogovernamentais e associações, com o objetivo de obter informações detalhadas sobre as manifestações e produções culturais e investigar as necessidades e prioridades do município com relação ao turismo. Foi possível conhecer um atrativo natural - cachoeira - e vivenciar duas importantes festas tradicionais com a apresentação da dança Catira. Os registros foram feitos por fotos digitais e vídeos. 
3. CARACTERIZAÇÃO DO AMBIENTE DE PESQUISA

\subsection{PÓLO ECOTURÍSTICO CHAPADA DOS VEADEIROS}

Após a construção de Brasília e o estabelecimento do Distrito Federal (DF) em 1960, o Brasil e, principalmente, o Estado de Goiás (GO) passaram por mudanças significativas. Novas estradas foram implementadas, surgiram novas indústrias e pólos urbanos. Em conseqüência destes fatores e das necessidades criadas pelo homem moderno, novos pólos e destinos turísticos se estabeleceram no domínio do cerrado brasileiro. A criação de UCs fortaleceu a sustentabilidade do estado e garantiu-Ihe maior oferta turística.

São três os pólos ecoturísticos do Estado de Goiás, segundo a Embratur: Chapada dos Veadeiros, Serra dos Pireneus e Parque das Emas. Estes constituem $13,9 \%$ da área do estado.

Os principais municípios que integram o pólo Chapada dos Veadeiros são Alto Paraíso de Goiás, Cavalcante, Colinas do Sul, Posse, São João D'Aliança, São Domingos e Teresina de Goiás. Para o enfoque da pesquisa em São João D'Aliança, faz-se necessário descrever e visualizar a região da Chapada dos Veadeiros e sua Unidade de Conservação. 


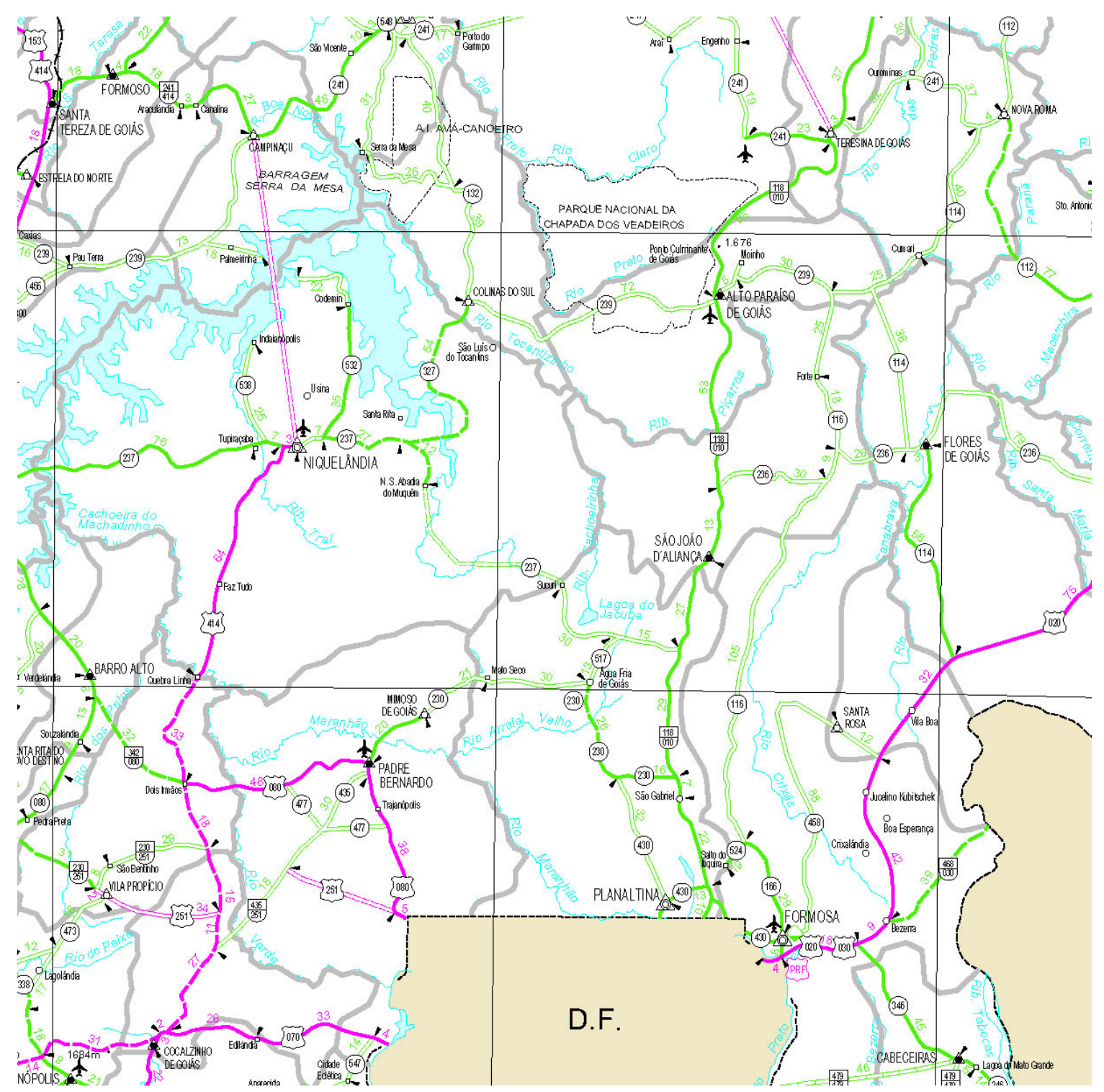

Mapa rodoviário - Goiás. DNIT - Departamento Nacional de Infra-Estrutura de Transportes.

Por possuir o mais antigo patrimônio geológico do continente, a placa Araí, formada há 1,8 bilhão de anos, a Chapada dos Veadeiros é o ponto de maior luminosidade visto da órbita da Terra, segundo a NASA. Trata-se do principal ponto de ecoturismo em torno da capital brasileira e uma das principais referências nacionais pelas belas paisagens, inúmeras cachoeiras, trilhas, singulares formações rochosas, fauna, flora, cultura e história. Por estes motivos, o ecoturismo, o turismo místico e o cultural atraem milhares de turistas para a região a cada ano. 
O atrativo turístico mais importante para este último pólo é, sem dúvida, o Parque Nacional da Chapada dos Veadeiros. Foi criado pelo Decreto $n^{\circ} 49.875$ de 11 de janeiro de 1961. A criação do Parque foi proposta pela Fundação Coimbra Bueno, em carta dirigida ao Presidente da República Dr. Juscelino Kubitschek em 04 de outubro de 1960. Daí surgiu o Parque Nacional do Tocantins, que depois teve seus limites alterados e mudou para Parque Nacional da Chapada dos Veadeiros. Anteriormente à sua criação, os moradores da região viviam da exploração de cristais e recursos naturais da área do parque. A partir da década de 1990, com o ordenamento da visitação, os garimpeiros receberam treinamento e hoje atuam como condutores de visitantes no parque, participam da gestão da unidade através do Conselho Consultivo e da preservação como um todo. No mês de junho de 2001 , foi criado o Conselho Consultivo da unidade, em setembro houve a ampliação da área da unidade e no mês de dezembro a unidade foi reconhecida pela UNESCO como Patrimônio Mundial Natural.

O parque possui uma área de 65.515 hectares. O acesso é feito através da BR-020, saindo de Brasília e seguindo por $220 \mathrm{Km}$ pela GO-118 em direção a Alto Paraíso, passando pelos municípios de São Gabriel e São João D’Aliança. Daí dobra-se à esquerda pela GO-239 por mais $28 \mathrm{Km}$ em estrada de terra, chegando à Vila de São Jorge, que pertence ao município de Alto Paraíso e é o portal de entrada do parque. A unidade fica a $260 \mathrm{Km}$ de Brasília.

O clima da unidade é típico da região dos cerrados brasileiros, marcado por uma época seca que tem o seu auge em setembro. Esta época é perigosa devido as freqüentes ocorrências de fogo. Nos meses de novembro a fevereiro as chuvas tornam-se intermitentes. A unidade está em terras que oscilam entre 1.400 e 1.700 metros. A fitofisionomia típica em toda área do parque é a do cerrado, que em sua 
maioria, representado pelos campos limpos, campos sujos e veredas acompanhadas de matas ciliares. Nos campos e veredas, belíssimas formações da palmeira buriti, que acompanha lugares úmidos, desde as nascentes prosseguindo por brejais e cursos d'água. A fauna é vasta, porém merece destaque o lobo-guará e o cervo do pantanal. As aves mais encontradas são a ema, o urubu-rei e várias espécies de gaviões. O pato mergulhão constitui espécie endêmica.

Além da Vila de São Jorge inserida no município de Alto Paraíso, Cavalcante e Colinas há alguns anos tiveram um desenvolvimento social e econômico por conta da atividade turística. Graças à demanda turística do parque nacional, serviços de hospedagem, alimentação, transporte e guiagem são oferecidos pela população local, que se beneficia com as oportunidades de trabalho e com o dinheiro deixado pelos turistas.

\subsection{O MUNICÍPIO DE SÃO JOÃO D’ALIANÇA}

Localizado entre os paralelos $14^{\circ} 20^{\prime \prime}$ e $14^{\circ} 50^{\prime \prime}$ e os meridianos $47^{\circ} 20^{\prime \prime}$ e 47 50", São João D’Aliança está a 160 Km de Brasília. O município, segundo o Instituto Brasileiro de Geografia e Estatística (IBGE), tem extensão territorial de 3.327 Km² e sua altitude varia entre 400 e 1280 metros. São João limita-se, ao norte, com Alto Paraíso; ao sul, com Água Fria de Goiás e Formosa; a leste, com Flores de Goiás; e a oeste, com Niquelândia. São João D'Aliança é cortado pela GO-118, rodovia que integra toda a região nordeste de Goiás. 
O clima característico de São João é o tropical úmido. As estações climáticas são bem definidas, sendo que a seca se estende do mês de maio ao mês de setembro e a estação chuvosa vai do mês de outubro ao mês de abril. A topografia é marcada pela presença da Serra Geral do Paranã, atravessando o município de Norte a Sul. A vegetação é caracterizada por áreas de transição entre cerrados e florestas úmidas pré-amazônicas. Seus principais rios, ribeirões e córregos, afluentes do rio Tocantins, oferecem condições privilegiadas para o ecoturismo e os esportes radicais. Um dos mais importantes rios do Brasil, o rio Tocantins tem mais de $2.700 \mathrm{~km}$ de extensão, desde as nascentes a mais de 1.100 m de altitude, na Estação Ecológica de Águas Emendadas (DF) e na Lagoa Formosa (GO). O rio das Brancas corre no município, passando por áreas de cânions e formando cachoeiras, ainda inexploradas, em propriedades particulares. O rio que divide os municípios de Alto Paraíso e São João D’Aliança é o rio Macaco. Junto com o rio Maranhão, nascido próximo à divisa de Goiás com o Distrito Federal, o Tocantinzinho é um dos principais formadores do rio Tocantins, que corta os estados de Goiás, do Tocantins e do Pará, desaguando no Atlântico. A origem de sua bacia está na Estação Ecológica de Águas Emendadas.

Conforme dados do IBGE do ano de 2001, as pessoas residentes em São João, tanto em área rural quanto urbana, somam 6.918 habitantes.

A atual sede do município surgiu no início do século $X X$, como povoado de trabalhadores da Fazenda Olhos D'Água, às margens do Ribeirão Capetinga. Em 1910 era arraial com nome de Capetinga e capela dedicada a São João Batista. Em 1913 passou à categoria de vila com o nome de São João da Capetinga. Era parte do distrito do Forte (povoado que hoje é distrito de São João D’Aliança) no município de Formosa. Nessa época surgem as primeiras tropas de carros de bois e cavalos, 
que iam de Formosa a Catalão, adquirindo gado e vendendo mercadorias. A Coluna Prestes atravessou o município, passando pelas mesmas trilhas cavaleiras, entre 11 e 20 de setembro de 1926. Com a campanha eleitoral da Aliança Liberal, uma comitiva de políticos visitou por várias vezes a vila de São João da Capetinga. Em um desses encontros Teotônio Fernandes e Nereu Ramos proclamaram a mudança de nome da vila para São João D'Aliança, por ser este local o ponto de apoio da Aliança Liberal. O Ribeirão da Capetinga também foi rebatizado com o nome Ribeirão das Brancas em homenagem a belas mulheres que ali se banhavam. Em 22 de abril de 1931 São João D'Aliança é elevada à categoria de município, mas entre 1939 a 1953 é reintegrado ao município de Formosa. A Segunda emancipação se deu em 13 de novembro de 1953, sendo efetivada em 01 de janeiro de 1954.

\subsubsection{ATRATIVOS NATURAIS E CULTURAIS}

Informações como atrativos turísticos do município foram retiradas do relatório da terceira fase - Definições de Estratégias de Desenvolvimento Turístico para o Município de São João D’Aliança - do Programa Nacional de Municipalização do Turismo (PNMT). Este programa, desenvolvido e coordenado pelo EMBRATUR, pretende, através dos comitês estaduais e de conselhos municipais, o fortalecimento do turismo sustentável, diante da preservação e valorização dos aspectos ambientais, históricos e culturais dos municípios brasileiros.

Os atrativos naturais de São João compreendem as cachoeiras: Pastor ou Veadeiros, Retenten, Label, São Pedro, Ribeirão, Buritizinho, Buracão, Pilão, do 
Francisco, Veredas, das Brancas, Mingau, Carestia, Vento, Andorinhas, do Jonas, do Zezé, do Ney e da Bucaina / Farias. Os mirantes são: do Vale do Paranã, do Vale de São Pedro e da Serra do Bonito. Os dois cannions são chamados de Macacão e Macaquinho. Vermelho, Viola, Ribeirão, Veadeiro/Pastor, Buritizinho e Vãozinho são córregos. Há ainda os ribeirões: Tocantinzinho, das Brancas, Cachoeirinha, São Pedro, Retenten e Extrema. As trilhas que podem ser percorridas são a do Forte e da Pedra de Amolar.

As manifestações populares, o artesanato e os produtos do extrativismo natural constituem os atrativos culturais de São João D'Aliança. São eles:

- Festas: Festa de São Sebastião, Folia de Reis, Festa São João Batista, Festa do Divino Pai Eterno, Festa de Nossa Senhora Santana, Festa da Rainha e Caçada da Rainha, Festa de Nossa Senhora D'Abadia, Festa de Nossa Senhora do Livramento, Festa de Nossa Senhora Aparecida, Festa da $2^{a}$ Emancipação do Município, Festa de Nossa Senhora da Conceição, e Festa de Santa Luzia;

- Feira de São João;

- Danças / músicas: Catira, Curraleira, Congado e tradições gaúchas;

- Artesanato: tecelagem com palha e algodão, bijuteria de sementes, móveis de buriti, pintura em pedra, pintura em tela, pintura em concha (indaiá), desenhos à lápis, cartões postais etc;

- Produtos típicos variados: farinhas, castanhas, mel, geléias, rapadura, gergelim, requeijão etc. 


\subsubsection{DEMANDA TURÍSTICA}

Foi realizada uma estimativa tomando por base o conhecimento dos participantes da oficina - PNMT. Os participantes caracterizaram as pessoas que chegaram em São João D'Aliança em: turistas, viajantes, visitantes e passantes.

Os turistas habituais somam um número de 2.200 pessoas por ano. A maioria deles - 90\% - é do Distrito Federal, 08\% é do entorno e 02\% de outras origens. A faixa etária dos turistas constitui 50\% com menos de 18 anos, 30\% entre 18 e 40 anos, 15\% com idade superior a 40 e inferior a 65 anos e $05 \%$ com mais de 65 anos. Há turistas femininos em maior número - 57\% - e 43\% do sexo masculino. O motivo da viagem é lazer $-100 \%$. O tempo de permanência dura de 02 a 04 dias e o gasto médio por dia é de $\mathrm{R} \$ 80,00$.

Caracterizados por somente pernoitarem, os viajantes são em média 12.000 por ano, sendo $70 \%$ de outros estados do Brasil, $20 \%$ do entorno e $10 \%$ do DF. Apenas $10 \%$ dos viajantes tem menos de 18 anos, $60 \%$ tem entre 18 e 40 anos e 30\% tem mais de 40 e menos de 65 anos. Viajam à negócios $80 \%$ das pessoas e $20 \%$ à lazer. O gasto médio diário é de $\mathrm{R} \$ 15,00$.

Os turistas que se hospedam em casas de parentes são considerados como visitantes, somando 35.000 pessoas ao ano.

A maior demanda turística para o município, em quantidade de pessoas, é constituída por passantes. Estes, aproximadamente 150.000 pessoas, são os que 
passam por São João para abastecerem seus automóveis e/ou fazerem uma refeição.

\subsubsection{INFRA-ESTRUTURA E SERVIÇOS}

A infra-estrutura e os serviços turísticos de São João D'Aliança englobam os meios de hospedagem (03 hotéis e 01 pousada, totalizando 265 leitos): Atos Hotel (140 leitos), Hotel Fernandes (15 leitos), Atos Hotel Fazenda (80 leitos), Pousada Aldeia da Serra (20 leitos); alimentação (restaurantes, lanchonetes e panificadoras): Restaurantes Chapéu de Sol, Atos, Quero Mais, Ramos, Galícia e Paladar Mineiro; Lanchonetes Sabor Natural, Posto Galícia, Recanto e Sabores, Aliança, Ponto Verde, Fim de Tarde, da Chiquinha, Los Primos, Batista, da Rodoviária e Kibacana; Panificadoras São João, Olhos D’água, Nunes, do Pimenta e Gaúcha; a operadora Giro Ecoturismo, a Escola Bioma Cerrado e a Agência de Desenvolvimento Capetinga (AD Capetinga) funcionam na Casa da Capetinga, ao lado da Igreja Matriz.

Constitui infra-estrutura de apoio turístico o sistema de segurança: Delegacia de Polícia Militar e Civil, Posto da Polícia Rodoviária Estadual; o sistema de transporte rodoviário: ônibus (diário) das empresas ESA, Real Expresso, União, São José do Tocantins; os transportes alternativos como as vans e os micro ônibus; o terminal rodoviário (rodoviária); o sistema de comunicação: telefones públicos, telefones fixos e celulares - sistema DDD/DDI, agência de Correios; emissora de 
rádio comunitária Vale FM, canais de televisão (retransmissão), internet; o sistema de saúde: hospital com 20 leitos, Programa Saúde da Família com 24 agentes de saúde, 03 clínicas odontológicas, 02 farmácias, 01 clínica espírita para dependentes químicos; outros: Banco Itaú, 07 oficinas mecânicas, Vídeo Locadora Canaã, casa lotérica, 05 salões de beleza; entretenimentos: ginásio de esportes, estádio municipal, clube municipal, Centro de Tradições Gaúchas - CTG, quadra poliesportiva comunitária.

A infra-estrutura básica de abastecimento de água e energia elétrica atende praticamente $100 \%$ da população urbana. A limpeza pública é terceirizada.

\subsubsection{ATORES SOCIAIS}

Vinculados ao turismo, os atores sociais têm fundamental importância ao desenvolvimento da atividade turística. Estes atores podem ser, desde que realmente atuem, a prefeitura, os meios de hospedagem, as agências e operadoras, os serviços de alimentação, de transporte e os turistas, já citados anteriormente. Estão incluídas também as entidades da sociedade civil organizada como as associações, os sindicatos, os conselhos e as organizações não governamentais.

Em São João as entidades organizadas são: Associação dos Guias de Ecoturismo e Meio Ambiente (AGEMA); Associação dos Pequenos Agricultores do Projeto de Assentamento Águas Claras II - APAPAC; Associação dos Moradores do Projeto Águas Claras I - AMPAC; Associação dos Produtores Rurais do Projeto de 
Assentamento Mingau - APPAM; Associação dos Produtores Rurais Assentados do Projeto Santa Maria do Paraná - APROSAMP; Associação dos Artesãos - ALIART; Organização das Mulheres das Águas - OMA; Sindicato dos Trabalhadores Rurais STR; Sindicato dos Produtores Rurais; Conselho Municipal de Turismo; Fórum de DLIS; e AD Capetinga.

\subsection{PATRIMÔNIO CULTURAL DE SÃO JOÃO D'ALIANÇA}

\subsubsection{A CATIRA DE SÃO JOÃO D'ALIANÇA}

Durante a Festa da Rainha deste ano, no vilarejo do Forte, foi possível conservar com o vice-presidente da Associação dos Catireiros, Carlos Ferreira, conhecido como Carlinhos.

Conforme esclarecimentos da conversa, a Associação foi fundada em 1997 e ainda não é um órgão registrado. Há pouco mais de 60 catireiros cadastrados, porém a metade deles tem maior interesse e participação nas questões da Associação, formando assim seus 36 membros. As reuniões dos catireiros acontecem de 15 em 15 dias no quintal da Casa da Capetinga, tendo uma média de duas reuniões por mês. Na maioria das vezes há ensaio da Catira nestes encontros. O espaço físico para os ensaios é pequeno e o chão de terra não é adequado para os sapateados da dança. Além da poeira das batidas dos pés, outro problema é o tipo de som do sapateado, que acaba sendo baixo e diferente do som que estão acostumados quando se apresentam em chão de madeira ou cimento. 
A origem da Catira de São João, segundo Carlinhos, não é muito conhecida; dizem que ela veio dos índios e dos negros. Ele lembra: "a lenda diz os primitivos daqui bateram os pés - sapatearam - para sentir a fertilidade do solo para o plantio e depois bateram palmas para agradecer a Deus pela chuva".

Na Catira de São João D’Aliança, os violeiros - "mestre" e "contra-mestre" cantam seus versos como "moda" ou "repente", de crítica à realidade vivida, relacionada à política, aos costumes ou aos acontecimentos locais, enquanto os catireiros sapateiam e batem palmas ao ritmo acelerado da marcação da viola. Vestidos com roupas e chapéu de vaqueiro, lenço colorido sob o colarinho e botas capazes de tirar do chão o som forte do sapateado, os catireiros, dispostos em duas filas, alternam-se dois a dois, em uma coreografia que sugere o trabalho pesado com a terra e o plantio. A dança e o canto da Catira traduzem uma memória corporal. O corpo e seus movimentos traçam uma identidade cultural.

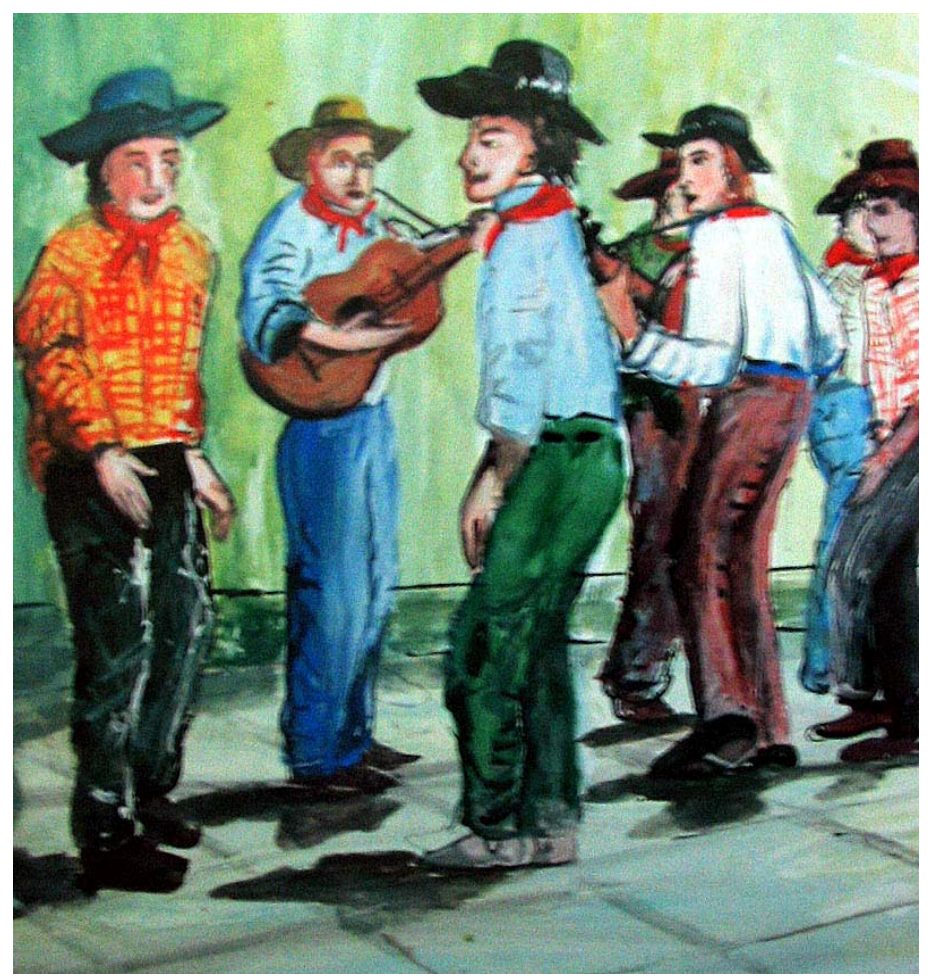

Tela de João Damasceno - A Catira, 2003 
O Professor Luiz Heitor, que pesquisou a catira em Goiás, afirma que a "grande arte dos catireiros está nos bate-pés e palmas, cujo ritmo é diferente a cada aparição de elementos coreográficos. A Catira é uma especialização coreográfica. Qualquer um não pode dançá-la".

\author{
"Parece uma coisa à toa \\ Mas tem muito que sabê; \\ Que não é qualquer pessoa \\ Que dança o cateretê!"
}

As manifestações tradicional-populares estão intimamente ligadas às raízes populacionais e fortemente fixadas em sentimentos e significados religiosos. Os eventos folclóricos, no Brasil, estão vinculados às comemorações da Igreja Católica.

Pôde-se perceber que as festas de São João D'Aliança se apóiam no Catolicismo e na fé nos santos da Igreja Católica. Estas festas são enriquecidas por rituais de reza e de dança. Portanto, é interessante para os turistas conhecerem e vivenciarem as manifestações festivas do município.

As festas citadas como atrativos culturais de São João D'Aliança são manifestações que promovem e valorizam a cultura. A Catira está inserida em reuniões festivas e em algumas festas religiosas do calendário.

Na Festa de São Sebastião, que acontece em janeiro, costuma-se fazer visitas às residências onde se dança Catira, reza-se o "bendito de mesa" (agradecimento da refeição oferecida pelo dono da casa) e cantam-se as ladainhas. O "alfer", encarregado da folia, é responsável pelo andamento do festejo e organização dos pousos nas fazendas, vilarejos e casas. 


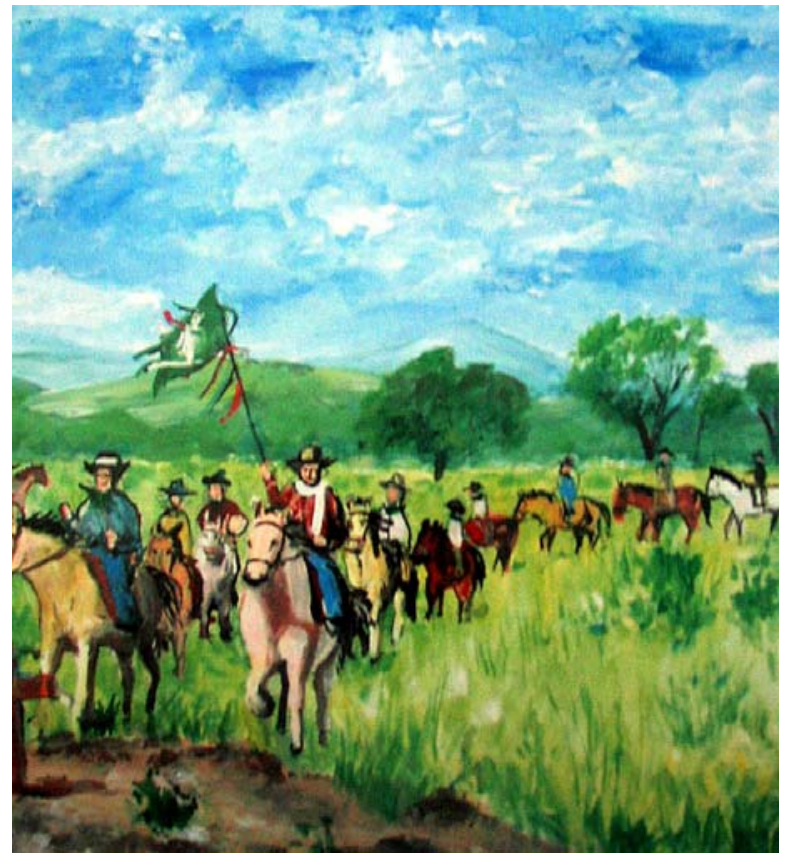

Tela de João Damasceno - Folia de São Sebastião, 2003

Sempre no primeiro domingo de julho se inicia a Festa do Divino Espírito Santo, tendo duração de uma semana. Os rituais de dança e reza são praticamente iguais aos da Festa de São Sebastião. Os turistas que participam da Festa do Divino acompanham os foliões por uma semana nas visitas à cavalo pelos pontos de pouso da região.

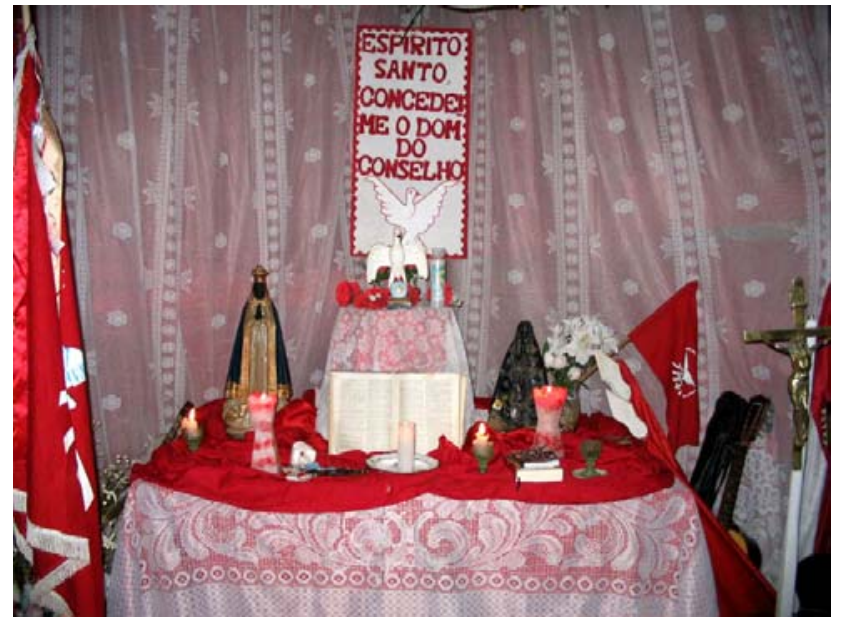

Altar da Festa do Divino - foto de Michelle Coelho, 2004 
Outra festa de grande significado cultural é a Festa da Rainha, realizada no vilarejo do Forte no mês de julho. A Caçada da Rainha é uma representação festiva da libertação dos escravos. De acordo com a lenda, a Princesa Isabel, após assinar a Lei Áurea, ficou receosa de que Dom Pedro II não concordasse com sua atitude. Ela, então, escondeu-se na mata ao saber da volta do imperador ao Brasil. Porém Dom Pedro ficou feliz com a libertação e ordenou que a Guarda Real promovesse uma caçada à Princesa Isabel. Os foliões do Forte saem pelo cerrado à captura da "rainha", escolhida pelos moradores da vila, e são recebidos com um grande batuque.

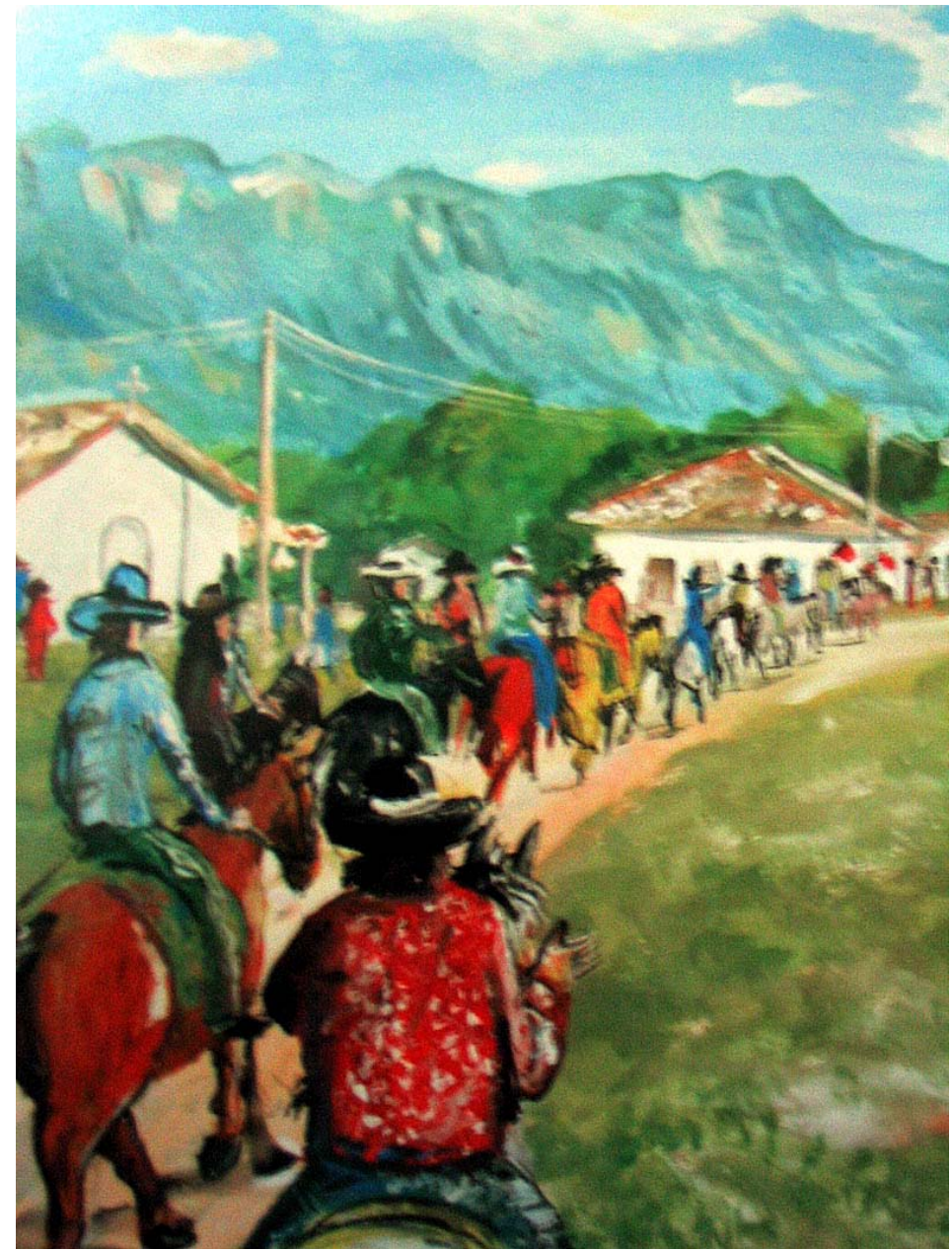

Tela de João Damasceno - Caçada da Rainha, 2003 


\subsubsection{O ARTESANATO E OS PRODUTOS TÍPICOS DE SÃO JOÃO D'ALIANÇA}

A peculiaridade do artesanato e dos produtos que são extraídos da riqueza do cerrado pode ser conferida por turistas que procuram a Casa da Capetinga, único local para se obter informações turísticas. A exposição dos produtos foi viabilizada através de parcerias da AD Capetinga, da APPAM, da ALIART e da OMA. Entretanto, o espaço físico para a exposição e a venda é pequeno e limitado.

Os principais artesanatos são a tecelagem com palha e algodão, tendo como produtos os tapetes, os "jogos americanos", os panos de prato, que são produzidos pelas mulheres da ALIART; as bijuterias de sementes do cerrado, produzidas por Antônio (do Assentamento do Mingau); os desenhos feitos por Ferraz; e as pinturas feitas por João Damascena. Os desenhos, pinturas e cartões postais não estão em exposição.

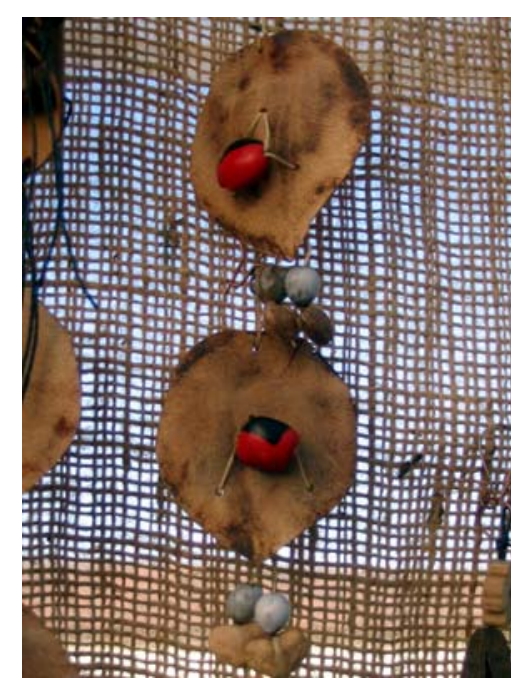

Bijuteria - Antônio

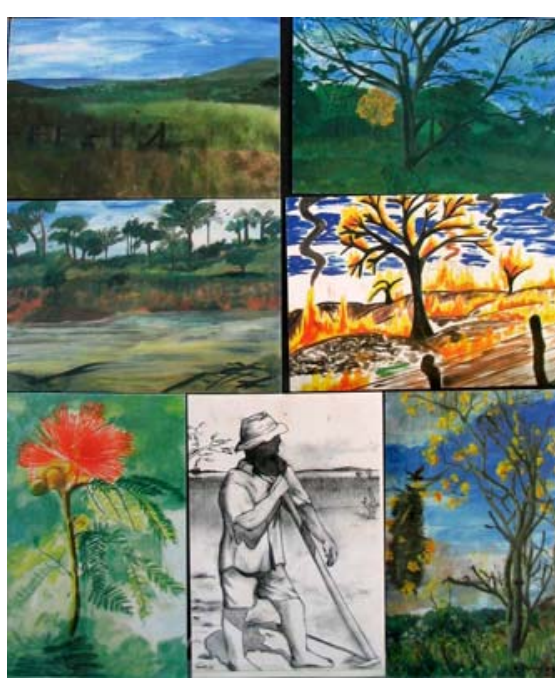

Postais - artistas locais

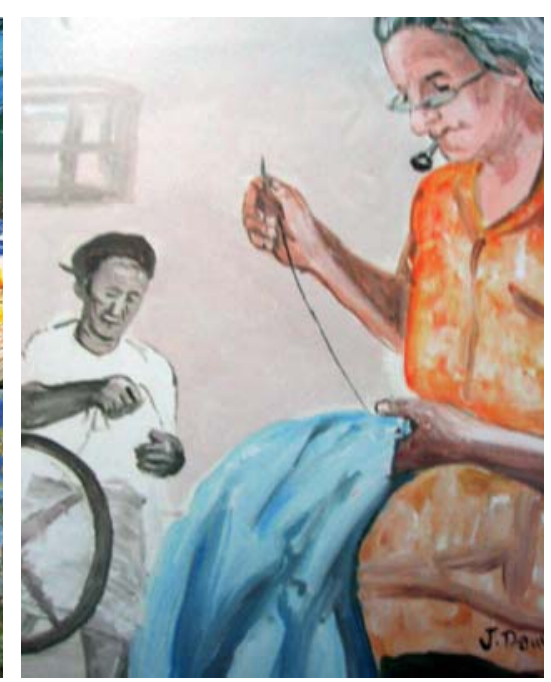

Tela - João Damasceno 

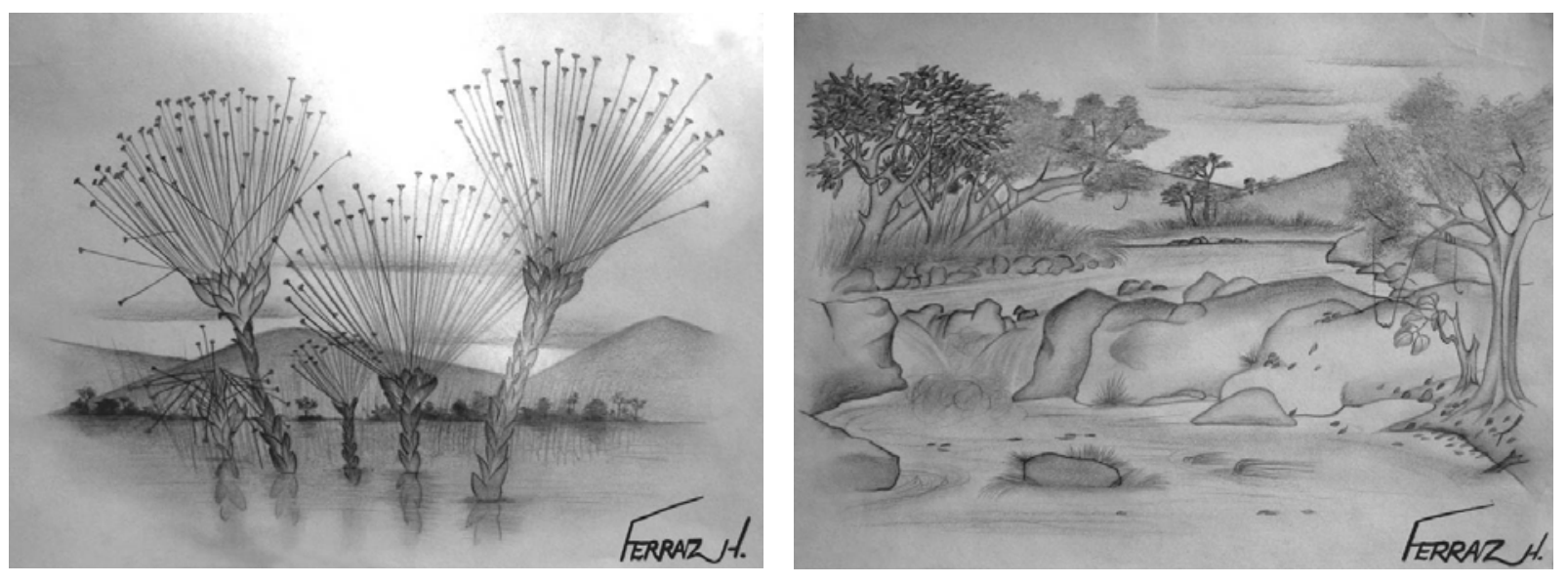

Desenhos - Ferraz

Descritos a seguir como são vendidos, a maioria dos produtos recebeu uma certificação de qualidade, nomeada Feira de São João, como resultado da parceria da $A D$ Capetinga e dos próprios produtores. Segundo Zéria, presidente da AD Capetinga, a parceria foi feita com o intuito de avaliar os produtos e orientar os produtores com noções de limpeza e higiene, de durabilidade e de embalagem de cada produto.

Os produtos são: Farinha de Jatobá, produzida pela OMA, validade: 12 meses, peso: 110 g; Farinha de Mandioca, produzida por Felipa Fernandes Vieira, validade: 6 meses, peso: 500 g; Barú Torrado (castanha de barú), produzido pela OMA, validade: 12 meses, peso: $50 \mathrm{~g}$; Mel de Flores do Cerrado, produzido por Zemar e Jacinto, validade: 6 meses; Geléias (abacaxi, cagaita, mangaba, vinagreira, jabuticaba, manga, jaca, maracujá, laranja, banana), validade: 6 meses, peso líquido: 45, 250 e 500 g; Casca de Laranja, produzida por Ilze Geiss de Almeida, validade: 12 meses, peso: 30 g; Gergelim, produzido por Santino Fernandes, 
validade: 12 meses, peso: 70 g; Rapadura e Rapadura com Amendoim, produzida no Assentamento do Mingau, pela Comunidade Pontezinha e Chácara Jacaré.

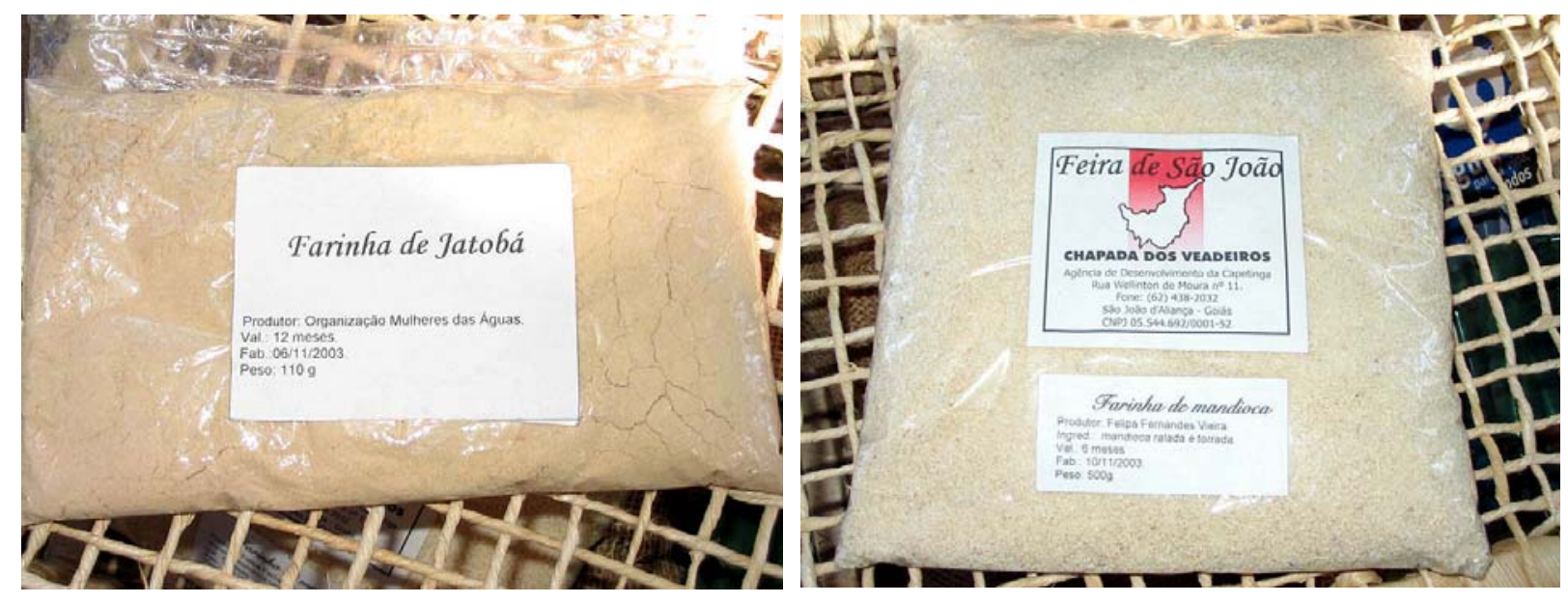

Farinha de Jatobá - OMA

Farinha de Mandioca - Felipa

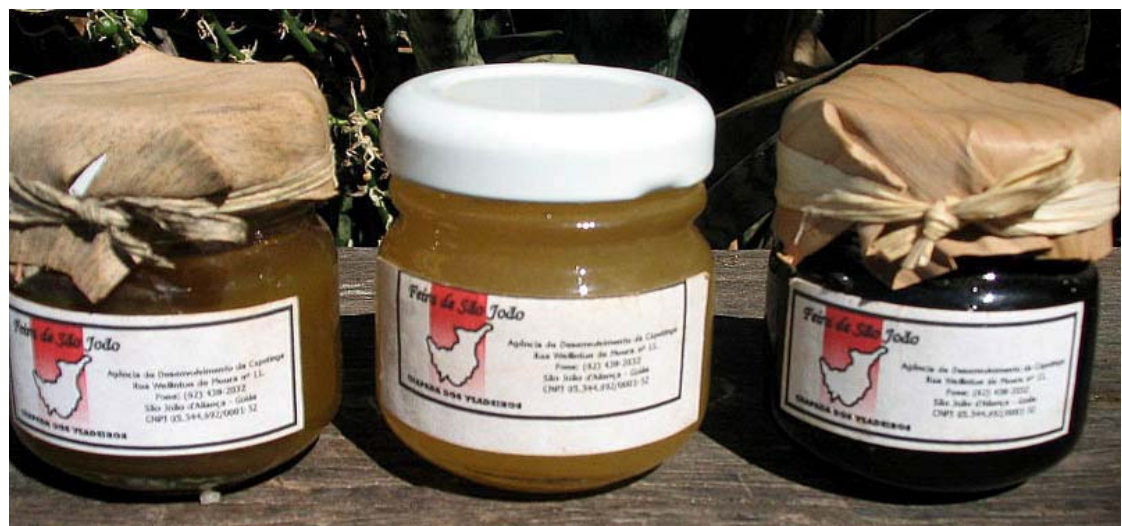

Geléias - OMA e Mel - Zemar e Jacinto 


\section{CRÍTICAS E SUGESTÕES}

Foi a partir da década de 1990 que o ecoturismo em São João D’Aliança ganhou maior importância devido à divulgação e expansão de Alto Paraíso e, principalmente, à proximidade com o Parque Nacional da Chapada dos Veadeiros. Considerada área núcleo da Reserva da Biosfera do Cerrado, a Chapada é referência nacional para o desenvolvimento do ecoturismo, abrigando o Parque Nacional, onde se trilha o caminho da sustentabilidade e da preservação de uma das maiores riquezas do Brasil: as águas.

A partir dessa idéia, a grande demanda do Parque Nacional juntamente à demanda já classificada de São João devem ser melhor aproveitadas. Para que isso ocorra, não basta somente a concretização de um espaço cultural como proposta isolada. Diversas ações precisam ser trabalhadas para o alcance do desenvolvimento sustentável do turismo na região. Porém, como não é possível aprofundar todas as etapas de um decente planejamento, o atual trabalho pretende priorizar a criação de um instrumento que sustente a cultura local e enriqueça a experiência do turista.

Constatou-se, por meio da pesquisa em campo, alguns pontos a serem melhorados: há pouca participação da comunidade com as questões do turismo; os atrativos naturais estão pouco desenvolvidos; a cultura local não está sendo valorizada da forma que merece; há uma carência geral de mão-de-obra qualificada; os serviços e a infra-estrutura são parcialmente qualificados; a paisagem local é desordenada e mal conservada; a prefeitura não está comprometida com as causas do turismo; há descaso do poder público em relação à promoção do turismo. 
Diante desta realidade, as ações que serão sugeridas poderão, se implementadas, dar suporte ao ecoturismo e, como objetivo principal, à salvaguarda da cultura local.

Para isso, o que se busca é a integração dos atores sociais para a realização de medidas como marketing e promoção do turismo, tanto como estratégia de divulgação do município como de informação para a comunidade; projetos de educação para o ecoturismo; formatação e manejo de acessos e trilhas para os atrativos naturais; implementação geral de sinalização turística: painéis, placas, letreiros, mapas e folders; incentivo aos projetos culturais; treinamento de pessoal; criação de uma Secretaria de Turismo e de um Fundo Municipal na área de turismo; entre muitas outras que incluem a melhoria da infra-estrutura básica do município. 


\section{PROPOSTA PARA A CRIAÇÃO DE UM ESPAÇO CULTURAL}

Pretende-se propor a concepção de um espaço cultural em São João D'Aliança que permita a visitação turística e o desenvolvimento de atividades da própria comunidade.

As razões para essa proposta de implementação vão desde a inexistência de um Centro de Atendimento ao Turista (CAT) em São João à integração cultural da Chapada dos Veadeiros.

A Casa da Capetinga, além de ser a sede da Giro Ecoturismo, da Escola Bioma Cerrado e da Agência de Desenvolvimento, exerce parcialmente a função de um CAT, divulgando mais especificamente os atrativos naturais e promovendo roteiros de descoberta da natureza, travessias e atividades esportivas de aventura. Como já visto, a Casa disponibiliza um pequeno espaço para a exposição e a venda dos produtos e artesanato. Portanto, o espaço poderá suprir as necessidades culturais dos turistas e complementar as atividades e serviços oferecidos pela Casa, mesmo que não idealizado propriamente como um CAT.

Lembrando que atualmente os ensaios da Catira acontecem no quintal da Casa da Capetinga e as condições são precárias para uma boa performance dos catireiros, a construção do espaço é, sem dúvida, uma solução para estes problemas.

O difícil acesso para os turistas aos eventos culturais onde a catira está inserida é uma outra razão. A realidade é que os turistas se limitam aos meses que as festas acontecem, tendo um acesso esporádico a esse tipo de atrativo cultural. Quando se programam para alguma festa, os turistas encontram dificuldades como a 
distância para as festas, as condições precárias das estradas de terra, a falta de alguns meios de hospedagem e serviços de alimentação.

A Festa da Rainha, por exemplo, que acontece no Forte, fica a $80 \mathrm{Km} \mathrm{da}$ área urbana de São João. As estradas se encontram em estado ruim, devido aos buracos e ao estreitamento, além da falta de firmeza e segurança das pontes de madeira. O Forte possui apenas um restaurante de comida caseira. Os quintais das casas dos moradores da vila se transformam em áreas de camping para os poucos turistas e moradores dos municípios próximos.

O que se pretende, entretanto, não é criticar as condições de acesso e de infra-estrutura dos lugares onde há todo o contexto das festas, mas sugerir outra maneira mais simplificada do turista ter acesso às manifestações da cultura local. Daí a relevância do espaço, que permitirá que o turista conheça a Catira e se programe para vivenciar os festejos tradicionais.

A partir da observação em campo da estrutura urbana do município, percebeu-se que a melhor opção de localização para a construção do espaço cultural é ao lado da Casa da Capetinga e em frente à Igreja Matriz. Dessa forma, todas as pessoas que passam pela rodovia que corta a cidade conseguirão visualizar o espaço com facilidade.

A estrutura física do espaço será dividida em módulos. Estes módulos serão do tipo quiosque, dispostos em formato de círculo, para que se tenha uma área central em comum.

O módulo de música e dança contemplará, primeiramente as atividades da Catira. Os ensaios passarão a ser abertos para o público - comunidade e turistas. Tem-se aí a importância da performance dos violeiros e catireiros, criadores de uma forma própria de expressão. A comunicação da performance, intensamente sensorial 
e emocional, tem o objetivo de envolver o público e provocar uma experiência. Além da sensação de satisfação para os "atores" que transmitem seus conhecimentos corporais e musicais. Haverá também aulas de Catira ministradas por catireiros mirins, adultos e femininos. Nesse caso, a oportunidade de ensinar passa a ser um estímulo para os "professores", que desenvolvem a capacidade de transmissão cultural e trabalham a auto-estima. Alguns produtos que estarão à venda neste módulo são: o Calendário das Festas e Tradições do Cerrado, que foi lançado em janeiro de 2004 através de parcerias da Organização das Mulheres das Águas,.da Universidade de Brasília e do Centro de Apoio para Sociedades Sustentáveis; o CD de músicas e modas da Catira, que está em processo de gravação e conta com o apoio da OMA; o CD de vídeos das festas tradicionais em São João D'Aliança, incluindo a história do município, apenas idealizado.

O módulo de artesanato como os cartões, as bijuterias, as telas, os tapetes e produtos como o mel, as geléias, as castanhas, as farinhas e a rapadura será um espaço para os produtores da cultura local e para os turistas. A exposição e venda destes produtos dependem de parcerias das associações e organizações do município para que se tenha um compromisso de qualidade. Um trabalho que se pretende desenvolver é o "Caminho da Roça", uma espécie de passeio pelas chácaras, fazendas e assentamentos onde são produzidos os doces, farinhas etc. O turista acompanhará de perto o processo de extrativismo natural e produção tradicional. Para isso, o espaço disponibilizará, se houver necessidade, os carros adequados e os guias culturais que acompanharão o passeio. Porém, a realização dessa idéia vai depender do interesse dos produtores e proprietários de estarem recebendo os turistas. 
Para uma melhor integração e desenvolvimento de parcerias, o módulo das entidades organizadas de São João permitirá o encontro das pessoas que se interessam e acreditam que o turismo possa beneficiá-los.

Os benefícios que se pretende atingir com a criação do espaço:

- Para o município: geração de impostos (Fundo de Turismo);

- Para a comunidade local: facilidade para exposição e venda dos produtos, retorno financeiro com as vendas, desenvolvimento da capacidade de ensinar a Catira, disponibilidade de espaço para os ensaios da Catira, integração das entidades organizadas, participação das questões culturais e turísticas;

- Para os turistas: acesso e conhecimento do patrimônio cultural; vivência da Catira por meio de aulas ministradas por catireiros; disponibilidade dos produtos locais para compra; acesso facilitado à informação através de programações culturais.

- Para o ecoturismo: sustentabilidade cultural. 
CONCLUSÃO

A sustentabilidade do turismo constitui desafio à sociedade. Foi esclarecido, para o caso de São João D'Aliança, que a valorização de seu patrimônio cultural poderá enriquecer o ecoturismo da Chapada dos Veadeiros.

Constatou-se que a localização de São João é privilegiada, porém sua demanda turística, junto à demanda do Parque Nacional, devem ser melhor aproveitadas. Há diversas ações que ainda precisam ser concretizadas para a resolução dos problemas locais e para o desenvolvimento turístico do município. A proposta de criação de um espaço cultural constitui um instrumento capaz de preservar a cultura popular e, naturalmente, agregar valor ao ecoturismo. Se implementado, o espaço proporcionará a salvaguarda de manifestações culturais como a Catira e os artesanatos e produtos locais assim como o bem estar da comunidade e dos turistas. Portanto, a mobilização social é fundamental para a realização de propostas desafiadoras que tenham como objetivo o alcance do turismo sustentável. 
BIBLIOGRAFIA

ARAÚJO, BERNADETE. Folclore: interiorizando a informação cultural. Cuiabá: SEC, 1997.

EMBRATUR / IBAMA. Diretrizes para uma política nacional de ecoturismo. Brasília, 1994.

FERRI, Cássia, RUSCHMANN, Doris. Revista Científica do Mestrado em Turismo e Hotelaria da Universidade do Vale do Itajaí. Itajaí, ano 2, n. 4, fev. 2000.

IGNARRA, Luiz Renato. Fundamentos do Turismo. São Paulo: Pioneira, 1999.

IRVING, Marta de Azevedo; AZEVEDO, Júlia. Turismo: o desafio da sustentabilidade. São Paulo: Futura, 2002.

INSTITUTO BRASILEIRO DE GEOGRAFIA E ESTATÍSTICA - IBGE. Dados estatísticos sobre o município de São João D'Aliança. Disponível em: <http://www.ibge.gov.br/cidadesat/default.php>. Acesso em 16 fev.2004.

INSTITUTO BRASILEIRO DE TURISMO - EMBRATUR. Pólos de ecoturismo: planejamento e gestão. Wendel de Magalhães, Guilherme (coordenador). 1 ed. São Paulo: Terragraph, 2001. 
LONDRES, CECÍLIA. Patrimônio e performance: uma relação interessante. In: TEIXEIRA, JOÃO GABRIEL L.C., et al (Org). Patrimônio imaterial, performance cultural e (re)tradicionalização. Brasília: ICS - UnB, 2004.

MINISTÉRIO DO TURISMO. Programa Nacional de Municipalização do Turismo Oficina de Terceira Fase: Definições de Estratégias de Desenvolvimento Turístico de São João D’Aliança - Goiás. Casa da Capetinga - São João D'Aliança, dezembro de 2003.

MONTORO, TÂNIA (Org.). Cultura do Turismo: desafios e práticas socioambientais. Brasília: Thesaurus, 2003.

OMT. Agenda 21 for the travel and tourism industry: towards environmentally sustainable development. Madrid, 1994.

SANTOS, JOSÉ LUIZ DOS. O que é cultura. $14^{\mathrm{a}}$ ed. - São Paulo: Brasiliense, 1996. - (Coleção Primeiros Passos, 110).

WWF-BRASIL. Manual de ecoturismo de base comunitária: ferramentas para um planejamento responsável. Mitraud, Sylvia (Org.). Brasília, 2003. 